DOI:10.17951/h.2015.59.2.139

\begin{tabular}{lcl}
\hline \multicolumn{1}{c}{ A N N A L E S } \\
UNIVERSITATIS MARIAE CURIE-SKŁODOWSKA \\
LUBLIN - POLONIA \\
VOL. XLIX, 2 & SECTIOH H \\
\hline
\end{tabular}

Uniwersytet Ekonomiczny w Krakowie, Katedra Międzynarodowych Stosunków Gospodarczych

IRENA PIETRZYK

e-mail: pietrzyi@uek.krakow.pl

\title{
Jednolity rynek europejski jako fundament i motor integracji europejskiej
}

The European Single Market as the base and driving force of European integration

Słowa kluczowe: jednolity rynek europejski, integracja europejska, Unia Europejska

Keywords: the European Single Market, European integration, EU

\section{Wstẹp}

Jednolity rynek europejski stanowi największy obszar gospodarczy na świecie i postrzegany jest jako kamień węgielny, a zarazem siła napędowa procesu integracji europejskiej. Podwaliny pod jego budowę stworzyły trzy traktaty założycielskie, lecz podstawowe znaczenie miał traktat rzymski z 1957 r., tworzący Europejską Wspólnotę Gospodarczą. Traktat ten wprowadził pojęcie wspólnego rynku, którego budowę kontynuować miał przyjęty 30 lat później Jednolity akt europejski (JAE). Ten ostatni wprowadził termin rynku wewnętrznego, lecz w rzeczywistości przyczynił się do upowszechnienia pojęcia jednolitego rynku, niesłusznie kojarzonego z tytułem traktatu. Pomimo wyznaczenia przez JAE na koniec 1992 r. docelowej daty zakończenia budowy wewnętrznego rynku europejskiego do dziś nie można jeszcze mówić o pełnej realizacji na jego obszarze tzw. czterech swobód, czyli o swobodnym przemieszczaniu się towarów, usług, ludności i kapitału między państwami członkowskimi. Dlatego też dwudziesta rocznica wejścia w życie JAE zaowocowała nowymi inicjatywami Komisji Europejskiej, mającymi doprowadzić do stworzenia „brakujących ogniw” w mechanizmie funkcjonowania rynku jednolitego. W artykule przedstawiono genezę i ewolucję budowy jednolitego rynku europejskiego, 
wskazano na jego znaczenie dla przyspieszenia dynamiki wzrostu gospodarczego oraz na problemy utrudniające dokończenie budowy wielkiego rynku europejskiego.

\section{Traktat rzymski i narodziny wspólnego rynku}

Budowa wspólnego rynku zapoczątkowana została traktatem paryskim z roku 1951 tworzącym Europejską Wspólnotę Węgla i Stali - EWWiS (który wszedł w życie 23 lipca 1952 r. i podpisany został na 50 lat, wygasając 22 lipca 2002 r.), lecz stosownie do celu traktatu ograniczona była jedynie do dwóch - ówcześnie strategicznych sektorów - węgla i stali. Stąd też koncepcja wspólnego rynku narodziła się faktycznie dopiero wraz z wejściem w życie 1 stycznia 1958 r. Traktatu ustanawiającego Europejska Wspólnotę Gospodarcza (EWG), podpisanego w Rzymie 25 marca 1957 r. Traktat tworzący EWG zapoczątkował integrację horyzontalną, obejmującą całość gospodarek narodowych państw członkowskich (w przeciwieństwie do integracji sektorowej, będącej celem traktatu paryskiego oraz drugiego traktatu rzymskiego tworzącego Europejską Wspólnotę Energii Atomowej - Euratom¹).

Zasadniczą misją utworzonej EWG stało się ustanowienie wspólnego rynku, lecz traktat nie zdefiniował tego pojęcia, a jedynie określił jego „treść”. Do zrealizowania podstawowego zadania przewidziano zniesienie opłat celnych i ograniczeń ilościowych między państwami członkowskimi (w przywozie i wywozie towarów) oraz wszelkich innych środków o skutku równoważnym, ustanowienie wspólnej taryfy celnej i wspólnej polityki handlowej wobec państw trzecich, a ponadto zniesienie między państwami członkowskimi przeszkód w swobodnym przepływie osób, usług i kapitału (art. 3 traktatu pkt a-c). Na stopniowe tworzenie zjednoczonej przestrzeni gospodarczej przewidziano $\mathrm{w}$ traktacie okres przejściowy 12 lat, podzielony na trzy czteroletnie etapy, w których ramach miały być podjęte konkretne działania tak, aby na koniec całego okresu (z maksymalną możliwością jego przedłużenia do lat 15) weszły w życie wszystkie regulacje prawne ustanawiające wspólny rynek (art. 8 traktatu o EWG).

Stosownie do zasad wolnej konkurencji traktat zabronił zarówno pozycji dominującej na rynku i zawierania porozumień między przedsiębiorstwami, jak i przyznawania - z wyjątkiem nielicznych derogacji - pomocy publicznej, która mogłaby naruszać handel między państwami i których skutkiem (zachowań przedsiębiorstw na rynku i pomocy państwa) mogłoby być uniemożliwianie, ograniczanie lub zniekształcanie swobodnych mechanizmów rynkowych (art. 85-94 dotyczące zasad konkurencji; obecnie art. 101-109 Traktatu o funkcjonowaniu Unii Europejskiej - TFUE).

1 Określenie to stworzył francuski polityk i przemysłowiec Louis Armand, pierwszy przewodniczący Euratomu [Gerbet, 1994, s. 167]. 
Całkowita likwidacja ceł importowych we wzajemnych obrotach nastąpiła jednak znacznie wcześniej niż zakładano, bo już od lipca 1968 r. [Płowiec, 2002, s. 23]. Wtedy także zrealizowana została unia celna, będąca efektem stopniowego wprowadzania wspólnej taryfy celnej stosownie do etapów liberalizacji wymiany wewnątrzwspólnotowej².

Znacznie trudniejsza do wprowadzenia niż unia celna i polityka handlowa (dotycząca ceł i kontyngentów wobec państw trzecich) była polityka rolna, w której nie chodziło jedynie - jak w przypadku produktów przemysłowych - o liberalizację wymiany między państwami członkowskimi, lecz o zastąpienie polityk krajów członkowskich polityką wspólną, prowadzoną przez instytucje wspólnotowe (Common Agricultural Policy - CAP). Rynek rolny z ustalonymi wspólnymi cenami dla niektórych produktów został otwarty 1 kwietnia 1968 r., a dla innych dopiero w roku 1970, „wymykając" się równocześnie obniżce taryf celnych w czasie negocjacji GATT.

Jeśli chodzi o pozostałe swobody na wspólnym rynku, to stopień ich realizacji był bardzo zróżnicowany. Przepływ pracowników miał już faktycznie miejsce przed 1958 r. i stał się całkowity od 1 października 1968 r. Co więcej, wprowadzone przepisy w sposób istotny poprawiały sytuację pracowników (z innych krajów członkowskich i ich rodzin), zbliżając ją do warunków pracowników krajowych. Wraz z ekspansją gospodarczą krajów „szóstki” migracje wewnątrzwspólnotowe zaczęły jednak tracić na znaczeniu na rzecz migracji zarobkowych pracowników z krajów trzecich (takich jak: Portugalia, Turcja czy kraje Maghrebu) w ramach umów dwustronnych, podpisywanych bez interwencji wspólnotowej.

O wiele trudniejsza okazała się liberalizacja usług, w której ramach z ułatwień korzystali handlowcy jeszcze przed powstaniem wspólnego rynku i którzy ostatecznie zostali zwolnieni z uzyskiwania zezwoleń na prowadzenie swojej działalności. Natomiast w odniesieniu do tzw. wolnych zawodów problemem stał się brak uznania ekwiwalentności dyplomów i obawa o interesy korporacyjne. Stąd też dopiero w drugiej połowie lat 70. XX w. doszło do wzajemnego honorowania dyplomów i do harmonizacji warunków dostępu do takich zawodów, jak: lekarze (1976 r.), adwokaci i pielęgniarki (1977 r.), dentyści i weterynarze (1978 r.).

Szczególnie rozczarowujące były efekty w zakresie liberalizacji transportu, mającego wyższy niż rolnictwo (bo 6\%) udział w tworzeniu wspólnotowego PNB. $\mathrm{W}$ traktacie rzymskim przewidziano wprawdzie wspólną politykę w zakresie transportu kolejowego, drogowego oraz śródlądowego (art. 74-84; obecnie art. 90-100 TFUE), lecz nie udało się doprowadzić do jej utworzenia, podobnie jak i do powstania, wspólnego rynku transportowego. Wyeliminowano wprawdzie dyskryminację między krajami członkowskimi w zakresie taryf i podatków, lecz o fiasku wolnego rynku i polityki w tej dziedzinie przesądziły ,,interesy narodowe” związane

2 W ramach dwóch kolejnych rund negocjacji GATT (runda Dillona i runda Kennedy’ego) EWG obniżyła znacznie bardziej swoją taryfę celną na produkty przemysłowe (bo do 6,9\%) niż Wielka Brytania, Stany Zjednoczone i Japonia (zmniejszenie odpowiednio do 11,6\%, 11,1\% i 10,1\%), [Gerbet, 1994, s. 215]. 
ze zróżnicowaniem znaczenia poszczególnych rodzajów transportu w państwach „szóstki” i ich faworyzowaniem przez poszczególne kraje (np. w przypadku Francji i RFN większe znaczenie transportu kolejowego, w Holandii i Włoszech - wodnego i drogowego) oraz z różnicami poglądów na stopień jego liberalizacji i niechęcią zrezygnowania z interwencjonizmu państwowego w tej dziedzinie (ze względu na społeczne i przestrzenne implikacje transportu).

Z kolei w zakresie liberalizacji przepływu kapitałów - wbrew propozycji Komisji utworzenia prawdziwego europejskiego rynku kapitałowego - państwa pozostały bardzo powściągliwe z uwagi na dążenie do ochrony krajowych źródeł finansowania, uniemożliwiania odpływu kapitałów krajowych i napływu kapitału spekulacyjnego czy wreszcie odmowę prowadzenia uzgodnionej polityki przepływu kapitałów wobec państw trzecich.

Podsumowując znaczenie traktatu rzymskiego dla procesu integracji, stwierdzić należy, iż dwoma filarami utworzonej Europejskiej Wspólnoty Gospodarczej stały się unia celna i wspólna polityka rolna, natomiast stworzenie wspólnego rynku, opartego na czterech swobodach, pozostało bardzo odległe od realizacji [Gerbet, 1994, s. 221].

\section{Jednolity akt europejski i proces budowy jednolitego rynku}

Jednolity akt europejski (JAE) był pierwszym traktatem, który w istotny sposób znowelizował zapisy traktatu rzymskiego. Celem JAE stało się dokończenie budowy wspólnego rynku, a używając terminologii przyjętej w tym traktacie - stworzenie wewnętrznego rynku europejskiego ${ }^{3}$, który zdefiniowany został - podobnie jak wspólny rynek w traktacie założycielskim z roku 1957 - jako „przestrzeń bez granic wewnętrznych, w której ramach zapewniony jest swobodny przepływ towarów, osób, usług i kapitałów" (art. 13 JAE; obecnie art. 26 p. 2 TFUE). JAE szedł jednak znacznie dalej niż traktat rzymski, posługujący się terminem ekonomicznym wspólnego rynku, ponieważ odwoływał się do idei bardziej politycznej - abolicji granic wewnętrznych [Roux, Schmidt, 1989, s. 6-7, 16].

\footnotetext{
3 Do użytku weszły trzy określenia (wspólny, jednolity i wewnętrzny rynek, stosowane zazwyczaj jako synonimy), których zniuansowaną interpretację podał w 1982 r. Trybunał Sprawiedliwości Wspólnot Europejskich, stwierdzając, że „wspólny rynek jest etapem procesu integracji międzynarodowej, który [...] zmierza do wyeliminowania wszystkich przeszkód w wymianie wewnątrzwspólnotowej celem połączenia rynków narodowych w rynek jednolity, realizując warunki możliwie najbliższe prawdziwemu rynkowi wewnętrznemu" (orzeczenie z 5 maja 1982 r., sprawa nr 15/81). Przy okazji warto wyjaśnić, że bardzo często przymiotnik , jednolity” interpretowany jest niesłusznie w przypadku rynku identycznie jak w odniesieniu do Jednolitego aktu europejskiego. Tymczasem w wypadku nazwy traktatu przymiotnik ten oznacza ujęcie po raz pierwszy w jednym traktacie regulacji wspólnotowych (czyli ponadnarodowych), dotyczących rynku wewnętrznego oraz międzyrządowych (czyli międzynarodowych), dotyczących europejskiej współpracy w dziedzinie polityki zagranicznej.
} 
Przygotowanie JAE poprzedziło ukazanie się białej księgi na temat zakończenia budowy rynku wewnętrznego ${ }^{4}$ [Commission des Communautés Européennes, 1985], w której Komisja zobowiązywała się do osiągnięcia najpóźniej w roku 1992 całkowitej unifikacji rynku wewnętrznego dzięki zrealizowaniu w tym celu niezbędnego programu. Program ten obejmował około 300 niezbędnych do podjęcia działań, które przybrały formę zaproponowanych przez Komisję i zaaprobowanych przez Radę dyrektyw, zobowiązujących państwa członkowskie do ich przetransponowania do prawa krajowego. Program utworzenia wielkiego rynku wewnętrznego przewidywał zniesienie do 31 grudnia 1992 r. granic fizycznych (tzn. zniesienia formalności i kontroli na granicach wewnętrznych odnośnie do towarów i osób, a także ich przeniesienie na granice zewnętrzne Wspólnot), technicznych (krajowych przepisów i norm technicznych stosowanych w państwach członkowskich) oraz fiskalnych.

Problemem bardzo „wrażliwym” stało się zapewnienie swobodnego przepływu osób, zwłaszcza wobec zdecydowanego sprzeciwu Wielkiej Brytanii. Stanowisko to sprawiło, że 5 państw (Francja, RFN i kraje Beneluksu) postanowiło samodzielnie przystąpić do opracowania rozwiązań zapewniających swobodny przepływ ludności między nimi, które to rozwiązania mogłyby zostać rozszerzone także na inne kraje. W tym celu 14 czerwca 1985 r. podpisały porozumienie w przygranicznej miejscowości w Luksemburgu, tworząc - od jej nazwy - tzw. grupę Schengen. W zawartym porozumieniu uzgodniły harmonizację wiz dla osób z krajów trzecich, walkę z nielegalną imigracją (ustanawiając sankcje dla przewoźników i odsyłanie imigrantów do krajów ułatwiających ich przyjazd), ochronę prawa azylu, zwalczanie przemytu narkotyków (dzięki utworzeniu biura łącznikowego policji europejskiej w Hadze) oraz walkę z przestępczością (dzięki wspólnemu systemowi informacji5).

Konwencja wykonawcza do porozumienia z Schengen podpisana została 19 VI 1990 r., a następnie ratyfikowana przez parlamenty narodowe. W dalszej kolejności do porozumienia przystąpiły wszystkie kraje członkowskie z wyjątkiem Irlandii i Wielkiej Brytanii, zaś konwencja z Schengen weszła ostatecznie w życie 26 marca 1995 r. $^{6}$. Z kolei przy okazji negocjowania traktatu amsterdamskiego - zarówno porozumienie z Schengen, jak i konwencja oraz wynikające z niej akty prawne -

4 Stosunkowo szybkie wprowadzenie proponowanych zmian nie byłoby możliwe przy dalszym utrzymaniu systemu jednomyślnego. Stąd też JAE zapoczątkował istotne zmiany instytucjonalne w funkcjonowaniu Wspólnot, modyfikujące zapisy traktatu rzymskiego (takie jak: rozszerzenie zakresu głosowania większościowego na forum Rady, zwiększenie kompetencji Komisji oraz prerogatyw Parlamentu Europejskiego - art. 6-12 JAE).

5 System Informacyjny Schengen (SIS) stanowi wspólną, elektroniczną bazę danych, zapewniającą zautomatyzowane procedury wyszukiwania informacji o osobach i przedmiotach. Składa się on z jednostki centralnej systemu, która znajduje się w Strasburgu (C-SIS), modułów krajowych (N-SIS) - działających w każdym państwie członkowskim uczestniczącym w SIS oraz infrastruktury komunikacyjnej między jednostką centralną i modułami krajowymi.

6 Aktualnie tzw. przestrzeń Schengen obejmuje 26 państw europejskich, tzn. większość państw członkowskich Unii Europejskich (z wyjątkiem Irlandii i Wielkiej Brytanii oraz Bułgarii, Rumunii, Cypru i Chorwacji), a ponadto 4 państwa członkowskie EFTA, a mianowicie: Norwegię, Islandię, Szwajcarię i Lichtenstein. Te ostatnie - z wyjątkiem Szwajcarii - utworzyły wraz ze Wspólnotą Europejską funkcjo- 
zostały zintegrowane z prawem Unii Europejskiej, stając się częścią składową acquis communautaire $\mathrm{z}$ chwilą wejścia w życie traktatu 1 maja $1999 \mathrm{r}$. .

Bariery techniczne natomiast, wynikające z przeszkód tworzonych przez ustawodawstwo krajowe, w większości zostały wyeliminowane, szczególnie w odniesieniu do wymiany towarowej. Istotny postęp w tym przypadku osiągnięty został już wcześniej, bo w 1979 r. dzięki orzeczeniu Trybunału Sprawiedliwości w sprawie cassis de Dijon [Dévoluy, Koenig, 2011, s. 240 i n.; Cini, 2007, s. 60 i n.]. Dotyczyła ona importu likieru francuskiego zawierającego $15 \%-20 \%$ alkoholu przez spółkę niemiecką w sytuacji, gdy prawo RFN zabraniało dystrybucji owocowych napojów alkoholowych o niższej niż 25\% zawartości alkoholu (z powodu rzekomego sprzyjania rozpowszechnianiu się alkoholizmu wśród młodzieży poprzez konsumpcję napojów o mniejszej zawartości alkoholu). Odwołanie do Europejskiego Trybunału Sprawiedliwości przyniosło jego decyzję mającą duże znaczenie dla prawa wspólnotowego uznającą, że produkt legalnie wytwarzany i sprzedawany w jednym państwie członkowskim może być także swobodnie dystrybuowany na całym terytorium Wspólnoty. Za wystarczający sposób ochrony interesu publicznego w tym przypadku uznana została informacja figurująca na opakowaniu produktu, podana do wiadomości konsumentów.

Jeśli chodzi o swobodę przepływu kapitału, to pierwotnie miała ona jedynie zapewniać właściwe funkcjonowanie wspólnego rynku (art. 67 traktatu rzymskiego). Jednakże działania na rzecz utworzenia jednolitego rynku sprawiły, że w roku 1988 przyjęta została Dyrektywa o implementacji art. 67 traktatu rzymskiego [Council, 1988], która zastąpiła dawne regulacje i przepisy i wyeliminowała wszelkie istniejące ograniczenia w tej dziedzinie. Dyrektywa ta wprowadziła faktyczną liberalizację przepływu kapitału z dniem 1 lipca 1990 r., potwierdzoną następnie w art. 73b traktatu z Maastricht (obecnie art. 63 TFUE), który swobodę przepływu kapitałów uznał jako warunek wstępny akcesji do unii gospodarczo-monetarnej. W ten sposób rynek przepływu kapitałów i płatności został całkowicie zliberalizowany przed przejściem do drugiego etapu unii gospodarczo-monetarnej, czyli przed 1 stycznia 1994 r. [Horváth, 2011, s. 245-246].

Ogólnie ocenia się, że do końca 1992 r. udało się przetransponować do prawa krajów członkowskich ponad $90 \%$ dyrektyw przewidzianych w celu utworzenia JRE ${ }^{8}$.

\footnotetext{
nujący od 1 stycznia 1994 r. Europejski Obszar Gospodarczy (EOG), w którego ramach obowiązują cztery swobody.

7 Zob. Protokót (nr 19) włączający dorobek Schengen w ramy Unii Europejskiej, Traktat o funkcjonowaniu Unii Europejskiej.

8 W niniejszym artykule ograniczono się jedynie do prezentacji najważniejszych działań podjętych w ramach tzw. integracji negatywnej (takich jak: likwidowanie technicznych barier handlowych, znoszenie kwot importowych czy eliminowanie wymogów licencyjnych itp.), natomiast w białej księdze znalazły się także instrumenty integracji pozytywnej, mające na celu korygowanie rynku (np. określenie standardów w zakresie ochrony zdrowia i bezpieczeństwa, zasady dotyczące znaków handlowych i ubezpieczeń depozytów, wskaźniki wypłacalności banków i towarzystw ubezpieczeniowych itp.), [Cini, 2007, s. 67-68].
} 
Najbardziej ograniczona pozostała jednak swoboda przepływu usług, której liberalizacja postępowała niezwykle wolno i przyspieszona została dopiero na przełomie lat 1980 i 1990, doprowadzając jeszcze przed końcem XX wieku do uwolnienia usług bankowych, finansowych, transportu lotniczego i telekomunikacji. Jednakże - z uwagi na rosnącą rolę sektora usług (zarówno w liczbie zatrudnionych, jak i wytwarzanym PKB) - sektor ten stał się głównym kryterium dobrego funkcjonowania i konkurencyjności Unii Europejskiej [Cini, 2007, s. 243]. Stąd też liberalizacja rynku usług uznana została za kluczowy element długofalowej polityki gospodarczej Unii Europejskiej i przyjętej w roku 2000 strategii lizbońskiej. Efektem tego było przedstawienie przez Komisję Europejską w styczniu 2004 r. projektu tzw. dyrektywy usługowej, którego autorem był unijny komisarz do spraw jednolitego rynku europejskiego Fritz Bolkestein. Celem projektu, stanowiącego pierwszą kompleksową regulację dotyczącą wykonywania usług w ramach jednolitego rynku europejskiego, było uregulowanie trzech kwestii:

1) usunięcia barier w swobodnym lokalizowaniu się przedsiębiorstw usługowych oraz ułatwienie ich rejestracji,

2) zapewnienie swobody świadczenia usług transgranicznych przez ułatwienie delegowania pracowników do innych krajów członkowskich,

3) wprowadzenie przepisów dotyczących pomocy wzajemnej państw członkowskich dla zapewnienia efektywnej realizacji tej dyrektywy.

Pomimo iż projekt wyłączał z zakresu działania dyrektywy niektóre rodzaje usług (głównie o charakterze użyteczności publicznej), wzbudził on wielki opór w krajach członkowskich z powodu wprowadzenia w nim tzw. zasady kraju pochodzenia w przypadku świadczenia usług transgranicznych. Oznaczała ona, że - poza nielicznymi, szczególnie uzasadnionymi przypadkami - usługodawca był zobowiązany do przestrzegania jedynie przepisów administracyjnych obowiązujących w kraju jego pochodzenia. Zasada ta wzbudziła obawy o możliwość nieuczciwej konkurencji ze strony nowych państw członkowskich z uwagi na niższe płace i standardy socjalne w tych krajach.

W konsekwencji w lutym 2006 r. Parlament Europejski przyjął znacznie zmieniony projekt dyrektywy Bolkesteina, z której wyłączony został szerszy katalog usług, a zasada kraju pochodzenia zastąpiona została przez zasadę swobody świadczenia usług i niedyskryminacji. Oznacza to, że żadne państwo członkowskie nie może dyskryminować usługodawcy z innego kraju członkowskiego, lecz powinno gwarantować mu prawo do świadczenia i wykonywania usług. Do ograniczenia tego prawa mogą znaleźć zastosowanie zasady konieczności i proporcjonalności jedynie w przypadkach dotyczących bezpieczeństwa, zdrowia, porządku publicznego i ochrony środowiska9 ${ }^{9}$.

9 Zob. Directive 2006/123/CE du Parlament Européen et du Conseil du 12 décembre 2006 relative aux services dans le marché intérieur (JO UE du 27.12.2006). Państwa członkowskie miały obowiązek wprowadzenia w życie przepisów wdrażających dyrektywę do 28 grudnia 2009. Dyrektywa ta została przetransponowana do polskiego systemu prawnego ustawą z 4 marca 2010 r. o świadczeniu usług na terytorium Rzeczypospolitej Polskiej (Dz. U. 26 marca 2010 r., nr 47, poz. 278), która weszła w życie 10 kwietnia 2010 r. 
Pobrane z czasopisma Annales H - Oeconomia http://oeconomia.annales.umcs.pl

Data: 26/04/2023 10:11:39

146

IRENA PIETRZYK

\section{Nowy etap budowy jednolitego rynku europejskiego w latach 2000-2010}

Jak się jednak okazuje, budowa jednolitego rynku jest procesem ciągłym, związanym zarówno z nadal niewykorzystanym w pełni jego potencjałem, jak i z pojawianiem się nowych wyzwań i uwarunkowań rozwoju. $Z$ jednej strony nadal mamy do czynienia z „deficytem” transpozycji unijnych dyrektyw do prawa narodowego krajów członkowskich, o czym informują regularne sprawozdania Komisji Europejskiej [Komisja Europejska, 2012], z drugiej - pojawiają się nowe rodzaje usług (jak np. internet), będące efektem innowacji i postępu technologicznego. Dlatego też pomimo dwudziestej rocznicy budowy JRE, która upłynęła w grudniu 2012 r., nie tylko tkwiący w nim potencjał nadal nie jest w pełni wykorzystywany, lecz zaobserwować można wręcz ,wyczerpywanie się wobec niego entuzjazmu" [Commission Européenne, COM(2010) 2020, s. 23]. Stąd też w swoim komunikacie dotyczącym lepszego zarządzania jednolitym rynkiem Komisja zaproponowała szereg środków mających na celu wzmocnienie zarządzania, określając najważniejsze obszary, które mogą ,przynieść największe korzyści pod względem wzrostu gospodarczego i tworzenia miejsc pracy" [Commission Européenne, COM(2012) 259].

Potrzeba zintensyfikowania procesu pogłębiania JRE stała się szczególnym wyzwaniem pod koniec okresu 2000-2010, kiedy to - podobnie jak w roku 1980 uznana została za najważniejszy atut Unii Europejskiej w walce z kryzysem. Wobec spowolnienia integracji i pojawiających się przejawów nacjonalizmu gospodarczego Komisja Europejska podjęła działania w kierunku nadania jednolitemu rynkowi nowej dynamiki w celu stworzenia bardziej solidnego, pogłębionego i poszerzonego rynku w ramach nowej strategii rozwoju, którą przedstawiła w swoim komunikacie Europa 2020. Strategia na rzecz inteligentnego i zrównoważonego rozwoju sprzyjającego wtaczeniu społecznemu [Commission Européenne, COM(2010) 2020, s. 23-24; Commission Européenne, COM(2012) 299]. Dlatego też pojawiły się inicjatywy Komisji zmierzające w kierunku eliminacji ,brakujących ogniw” JRE oraz zniesienia barier, które wciąż jeszcze utrudniają jego funkcjonowanie. Zapoczątkowanie działań w tym kierunku znalazło wyraz w zamówieniu przez przewodniczącego Komisji J.M. Barrosa 20 października 2009 r. u Maria Montiego (byłego komisarza europejskiego najpierw do spraw rynku wewnętrznego, a następnie do spraw konkurencji) specjalnego raportu mającego zawierać opcje i rekomendacje na rzecz ożywienia jednolitego rynku. Raport pt. Nowa strategia dla rynku jednolitego. W stużbie europejskiej gospodarki i społeczeństwa europejskiego [Monti, 2010] opublikowany został w pierwszej połowie $2010 \mathrm{r}$. i stanowił podstawę do sformułowania przez nowego komisarza M. Barniera, odpowiedzialnego od lutego $2010 \mathrm{r}$. za rynek wewnętrzny, propozycji nowych działań na rzecz jednolitego rynku, określonych mianem Single Market Act.

W swoim raporcie M. Monti stwierdził, że JRE jest niemal powszechnie postrzegany jako podstawowy sukces integracji, podczas gdy europejska integracja rynkowa spotyka się obecnie z ocenami sceptycznymi, czy nawet z jej odrzucaniem przez dużą część obywateli Unii Europejskiej. Tymczasem konieczne staje się kon- 
tynuowanie wysiłków na rzecz budowy JRE, ponieważ jego idea nic nie straciła na swojej aktualności, a wręcz przeciwnie: zwłaszcza w dobie kryzysu nabrała jeszcze większego znaczenia [Monti, 2010, s. 15].

Propozycje M. Barniera zostały zawarte w komunikacie komisji z kwietnia 2011 r. w dokumencie opublikowanym pt. Akt o jednolitym rynku-dwanaście dźwigni na rzecz pobudzenia wzrostu gospodarczego i wzmocnienia zaufania. Wspólnie na rzecz nowego wzrostu gospodarczego [Komisja Europejska, KOM(2011) 206; Barnier, 2011]. Wymienione w tytule dwanaście dźwigni ma na celu stworzenie silniejszego rynku jednolitego i odnosi się do następujących problemów:

1) ułatwienia małym i średnim przedsiębiorstwom dostępu do źródeł finansowania,

2) zwiększenia mobilności pracowników w ramach jednolitego rynku,

3) wprowadzenia europejskiej ochrony praw własności intelektualnej,

4) wzmocnienia zaufania konsumentów do jednolitego rynku europejskiego,

5) wzmocnienia normalizacji usług,

6) wzmocnienia sieci europejskich,

7) wzmocnienia zaufania do transakcji elektronicznych,

8) rozwoju przedsiębiorczości społecznej,

9) dostosowania systemu podatkowego do wymogów JRE XXI wieku i trwałego rozwoju,

10) wzmocnienia spójności społecznej w Unii Europejskiej,

11) uproszczenia przepisów prawnych dotyczących przedsiębiorstw,

12) unowocześnienia ram prawnych procedur przetargowych ${ }^{10}$.

Inicjatywy Komisji oraz zaproponowane przez nią działania spotkały się ze zdecydowaną aprobatą zarówno Parlamentu Europejskiego ${ }^{11}$, jak i Rady Europejskiej ${ }^{12}$.

W drugiej połowie $2012 \mathrm{r}$ Komisja dokonała przeglądu zrealizowanych działań i sformułowała dalsze etapy postępowania w nowym dokumencie, określonym

10 Szersze omówienie dwunastu dźwigni znaleźć można w cytowanym wyżej tekście komunikatu Komisji, określonym - po ukazaniu się następnego Aktu w roku 2012 - jako Pierwszy akt o jednolitym rynku. Wymienione dźwignie zostały wcześniej rozpisane na 50 konkretnych działań, które przedstawione zostały przez Komisję Europejską do konsultacji ogólnoeuropejskiej Vers un acte pour le marché unique - Pour une économie sociale de marché hautement compétitive: vu la Communication de la Commission „, Vers un acte pour le marché unique - Pour une économie sociale de marché hautement compétitive - 50 propositions pour mieux travailler, entreprendre et échanger ensemble", communication de la Commission au Parlement Européen, au Conseil, au Comité Economique et Social Européen et au Comité des Régions, Bruxelles le 27 octobre 2010, (COM(2010) 608 final); Bruxelles 13 avril 2011.

${ }^{11}$ Donner un marché unique aux consommateurs et aux citoyens, résolution du Parlement européen du 20 mai 2010; Un marché unique pour les entreprises et la croissance, résolution du Parlement européen du 6 avril 2011; rapport sur un marché unique pour les Européens 24 III 2011; sa résolution du 6 avril 2011 sur la gouvernance et le partenariat dans le marché unique, résolution du 1er décembre 2011; sur 1'acte pour le marché unique: les prochaines étapes vers la croissance (2012/2663(RSP); sur le résultat du Forum du marché unique qui s'est tenu à Cracovie, en Pologne, les 3 et 4 octobre 2011.

12 Conclusions du Conseil européen du 23 octobre 2011. 
mianem Drugiego aktu w sprawie jednolitego rynku [Commission Européenne, $\operatorname{COM}(2012) 573]^{13}$.

Dokument ten, wynikający z Pierwszego aktu o jednolitym rynku, identyfikuje 4 motory nowego wzrostu w Unii Europejskiej, na których powinny skoncentrować się kluczowe działania. Motory te dotyczą:

1) stworzenia w pełni zintegrowanych sieci na rynku europejskim,

2) ułatwiania mobilności transgranicznej obywateli i przedsiębiorstw,

3) wspierania gospodarki cyfrowej w całej Europie,

4) wzmocnienia przedsiębiorczości społecznej, spójności i zaufania konsumentów.

Zdaniem Komisji każde z wymienionych działań kluczowych przyczyniać się będzie do generowania wzrostu i tworzenia miejsc pracy, a tym samym do wzmocnienia zaufania obywateli do jednolitego rynku. Działania te są niezbędne, aby wizja wysoko konkurencyjnej społecznej gospodarki rynkowej stała się rzeczywistością. Równocześnie Komisja zobowiązała się do przygotowania całości niezbędnych propozycji legislacyjnych najpóźniej do końca 2013 r., zwracając się przy tej okazji do Parlamentu i Rady z zaproszeniem do przyjęcia tych projektów w trybie przyspieszonym najpóźniej do wiosny 2014 r. [Commission Européenne, COM(2012) 573, s. 19$]^{14}$.

\section{Zakończenie}

Budowa jednolitego rynku stanowi główne osiągnięcie procesu integracji europejskiej, w który - z wyjątkiem Szwajcarii - włączone zostały także kraje członkowskie EFTA, pozostające poza strukturami unijnymi, lecz wchodzące od 1994 r. w skład tzw. europejskiego obszaru gospodarczego. Jak wynika jednak z przedstawionej ewolucji - pomimo blisko 60 lat kontynuowania tego dzieła - nie tylko dalekie jest ono od ukończenia, ale wymaga wręcz ciągłego wysiłku na rzecz jego pogłębiania i reagowania na nowe wyzwania oraz obejmowania nim nowych dziedzin, wciąż jeszcze podlegających regulacjom i procedurom krajowym, utrudniającym faktycznie swobodny przepływ towarów, usług, ludności i kapitału. Swoje rozczarowanie dalekim od oczekiwań stanem postępów w budowie jednolitego rynku wymownie wyraził jeden z jego głównych architektów i długoletni przewodniczący Komisji Europejskiej - Jacques Delors, stwierdzając, iż niestety „trudno jest zakochać się w jednolitym rynku". Tymczasem - w jego przekonaniu - jednolity rynek stanowi kamień węgielny konstrukcji europejskiej, jako że historycznie ujmując - wbrew

13 Zob. także: Résolution du Parlement européen du 14 juin 2012 sur l'acte pour le marché unique: les prochaines étapes vers la croissance.

14 Jak wiadomo, obowiązki komisarza do spraw rynku wewnętrznego w nowej Komisji Europejskiej, która rozpoczęła swoją 5-letnią kadencję z dniem 1 listopada 2014 r., objęła Elżbieta Bieńkowska - była polska minister infrastruktury i rozwoju regionalnego. 
projektom integracji bardziej politycznej - zawsze preferowana była integracja ekonomiczna ${ }^{15}$.

\section{Bibliografia}

1. Barnier M. (2011), 12 chantiers pour le Marché Unique de 2012: ensemble pour une nouvelle croissance, $\mathrm{IP} / 11 / 469$.

2. Cecchini P. (1988), Le coût de la non-Europe, rapport établi sous la dir. de Paolo Cecchini.

3. Cini M. (red.) (2007), Unia Europejska. Organizacja i funkcjonowanie, PWE, Warszawa.

4. Commission des Communautés Européennes (1985), L'achevement du marché intérieur, Livre Blanc, Com(85) 310 final, Bruxelles, 14 juin 1985.

5. Commission Européenne, Communication de la Commission, Europe 2020. Une stratégie pour une croissance intelligente, durable et inclusive, Commission Européenne, Bruxelles 3.3.2010 COM(2010) 2020 final.

6. Commission Européenne, Communication de la Commission au Parlement Européen, au Conseil, au Comité Economique et Social Européen et au Comité des Régions, Une meilleure gouvernance pour le marche unique, Bruxelles 8 VI 2012, COM(2012) 259 final.

7. Commission Européenne, Communication de la Commission au Parlement Européen, au Conseil Européen, à la Banque Centrale Européenne, au Comité Economique et Social Européen et au Comité des Régions et à la Banque Européenne d'Investissement, Agir pour la croissancie, la stabilité et l'emploi, Bruxelles, le 30.5.2012, COM(2012) 299 final.

8. Commission Européenne, L'acte pour le marché unique II. Ensemble pour une nouvelle croissance, Communication de la Commission au Parlement Européen, au Conseil, au Comité Economique et Social Européen et au Comité des Régions, Bruxelles, le 3.10.2012 COM(2012) 573 final.

9. Council, Council directive of 24 June 1988 for the implementation of Article 67 of the Treaty (88/361/ EEC).

10. Delors J., Vingt ans après 1992, relancer le marché unique européen, „La Tribune”; http://www. notre-europe.eu.

11. Dévoluy M., Koenig G. (red.), L’Europe économique et sociale. Singularités, doutes et perspectives, Presses Universitaires de Strasbourg 2011.

12. Gerbet P. (1994), La construction de l'Europe, Imprimerie Nationale - Editions, Paris.

13. Horváth Z. (2011), Manuel sur l'Union Européenne, HVGORAC, Budapest.

14. Komisja Europejska, Akt o jednolitym rynku - dwanaście dźwigni na rzecz pobudzenia wzrostu gospodarczego i wzmocnienia zaufania. Wspólnie na rzecz nowego wzrostu gospodarczego, Bruksela 12 IV 2011, KOM(2011) 206, wersja ostateczna.

15. Komisja Europejska (2012), Tabela wyników rynku wewnętrznego: państwa członkowskie poprawity swoje wyniki, komunikat prasowy, Bruksela, 8.10.2012 r.

16. Monti M. (2010), Une nouvelle stratégie pour le marché unique. Au service de l'économie et de la société européennes, rapport au Président de la Commission européenne José Manuel Barroso présenté 9 mai 2010.

17. Perissich R. (2012), Marché unique: enjeux industriels et politiques, ,Tribune”, le 29 novembre 2012 , Institut Jacques Delors „Notre Europe”.

18. Płowiec U. (2002), Unia Europejska a Polska, Wyższa Szkoła Ubezpieczeń i Bankowości, Warszawa.

19. Roux X. de, Schmidt M.-F. (1989), L’Acte Unique Européen, „Juridiction Joly/Gide Nouel”, numéro spécial, Bureau d'information: Dictionnaire du Marché Commun, Bruxelles.

15 Wypowiedź z 21.11.2012 r.; cyt. za: „Notre Europe”. 
Pobrane z czasopisma Annales H - Oeconomia http://oeconomia.annales.umcs.pl Data: 26/04/2023 10:11:39

\section{The European Single Market as the base and driving force of European integration}

The European Single Market is a key factor in the process of European integration. Rudiments of its construction have been created by three founding treaties, but the most important was the Treaty of Rome (1957), establishing the European Economic Community (EEC). That treaty introduced the concept of the common market. Its construction was completed in accordance with the Single European Act adopted 30 years later. This treaty introduced the concept of the internal market, but in fact it contributed to spreading of the term single market, wrongly derived from the title of the treaty. Although the SEA imposed a deadline for the creation of the great European market at the end of 1992, it still remains unfinished. The article presents the genesis and subsequent stages of the European Single Market creation and indicates its importance for the economic growth acceleration, as well as the problems that hinder the completion of the European Single Market. 